\title{
An empirical study of e-Service quality and its impact on achieving a value added
}

\author{
Haitham M. Alzoubi \\ Skyline University College, Sharjah, UAE \\ Majeda Abdo \\ Ministry of education, Amman, Jordan \\ Anwar Al-Gasaymeh \\ Applied Science Private University, Amman, Jordan \\ Ali A. Alzoubi \\ Ajloun National University, Ajloun, Jordan
}

\begin{abstract}
Keywords
e-Service Quality, Website Services, Value Added.
\end{abstract}

\begin{abstract}
This study addresses the gap of how businesses vary in quality services of its website by investigating the e-Service Quality and its impact on achieving students' value added at private universities in Jordan. A descriptive and quantitative methodology are used. To achieve the study objectives. A Likert scale questionnaire was designed and included (30) statements to collect data from the sample which consists of (480) respondents. Then, a statistical correlations and regression tools used to analyze data.

The study showed that e-Service Quality related to achieving a student's Value Added. Findings have also proved the impact of e-Service quality on achieving students' Monetary value and achieving students' Beneficial value. Multiple regression indicated that "adequacy of information" and "website design" have the highest impact on achieving Value added. We concluded that sophisticated content, user-friendly wellconstructed, and professional university's web design would improve students' experience, and add much values to students.
\end{abstract}

Corresponding author: Haitham Alzoubi

Email addresses for the corresponding author: haitham_zubi@yahoo.com

First submission received: $17^{\text {th }}$ May 2018

Revised submission received: $3^{\text {rd }}$ September 2018

Accepted: 10th December 2018

\section{Introduction}

Globalization, hyper competition and information technology era push businesses to adopt new styles of management, and able to produce and deliver products and services that add values to customers. Also adopt any new methods to satisfy customers expectations. There is a consensus on how vital a website is important for any business, which is determined by its services. Businesses have to enhance their website and improve the quality of its web-services (e-Service Quality) to grant their customers with more values.

Businesses' website foreshadows the strategic tool of the new era of businesses due its great potential for being one of businesses' core competences for all types of industries. Services-based business may rely on website more than manufacturing-based business since website became part of its services like universities. A good university's website would improve students' interactions, strengthen institutional reliability and reputation, enhance students' satisfaction, and result in more saving in money and time. Moreover, universities that consider a good student experience of website influence to contribute to greater institutional goals and lead to obvious financial returns.

Service quality is seen as the ability to identify and respond to the declared or undeclared consumer interests. In the service-based, perception is an important aspect of the service experience, and an 
important part of quality of service. Quality in services is not what the supplier provides but what the customer receives (Khafajy et al., 2016).

Universities try to explore what and how students value their website and what they perceived to be value added, it reflects their level of satisfaction of website, as compared with that of its competitors. It is also important from industry-based viewpoint as well as service- based to understand the e-service quality in terms of online services and the determinants dimensions of the value perceived by the customer (Askari et al., 2016). Furthermore, service quality in online environment is a significant determinant of the productivity of e-service and the perceived value. Usually online customers expect a better or at least the same level of service compared to traditional service channels or compared to competitors' service level.

\section{Theoretical Framework and Literature Review}

Service quality of any website can be viewed as the sum of facilities and services provided by business' websites. Different perspectives on the importance of the quality of web services and the disparity in the level of services they provide, and their relationship to value added, make businesses rethink the framework of e-service and how to provide it to enhance the disparate relationships with added value (Chinomona et al., 2014). Chen et al. (2013), discussed that quality of service is making sure that business fulfill their customers' needs and requirements when using their website. And the quality level of websites' services could refer accordingly to the level of technical capabilities, level of design, facilitates processing their transactions, and quick response, that meet or exceed the customer's needs, which may contribute to build a good relationship with them (Alzoubi et al., 2015).

\section{E-Service Quality}

Although It is apparent that reviewing dimensions of service quality still with the interest of many authors regarding its number and nature identified (Ladhari, 2010). However, quality could be derived from the comparison of the existing service performance of any business with the customers' expectations and experiences. Also, service quality can be defined as surpassing the expectations of the customers. Moreover, Parasuraman et al. (2005) referred that dimensions of service quality consists of five criteria; namely tangibles, reliability, responsiveness, assurance and empathy. In addition, Ladhari (2010) explored most examined dimensions in the literatures, these dimensions were; Ease of use (reliability/trust), Quick accessible (accessibility), Adequacy of information (information quality/benefit), Website design (content), responsiveness, empathy, competence, interactivity, convenience, and accuracy.

In the same regard, Rust and Lemon (2001) agreed that e-service related to the function of services in an online environment. While the perceived e-service quality assessed by the consumer refers to consumers' overall assessment and perception of the services provided by the company's website, and to what degree the expectations of the consumers are fulfilled by the service outputs (Santos, 2003).

Some dimensions have been argued by Cristobal et al. (2007) in which customers assess websites such as: ease of use/usability, information accessibility/content, design style, privacy/security, and fulfillment. In addition, Rowley (2006) investigated dimensions of e-service quality which are: website features (design), security, responsiveness, accessibility, reliability (Ease of use), information (Adequacy), communication, delivery, personalization. While Parasuraman et al. (2005) introduced a model to measure the e-service quality (E-S-QUAL), consists of system availability, efficiency, privacy, fulfillment, contact, responsiveness, and compensation. The e-Service dimension adopted in this study followed the study of Ladhari (2010) which are; Quick accessible, Ease-of-use, Information Adequacy, and Website design.

Quick accessible: refers to website's mechanism to facilitate the reach and retrieve targeted information. Also, the ability to offer multiple access points of communication through various interfaces like search engine, that assist users to search and pick up relevant information (Cai and Jun 2003).

Ease-of-use: which enable the users to use all website's options, functions and services in Smooth, comfort and easy way. Moreover, it gives more simplicity to absorb content information which needs to be clearly articulated, also to offer internal tools to be simple to use (Li and Suomi, 2009). 
Information Adequacy: it's when the website provides the users with a sufficient, satisfied and relevant content of information as immediate as the users seek for it. In addition, content should cover all areas of interest, and information provided should be fit to users' requirements (Ladhari, 2010).

Website design: It refers to the website's architecture and all related aesthetics, like images, colors, animations and graphics, and how it is presenting the content in a way to attracts and motivate the website's user, that makes them return to use the website. And most likely, quality of design, happens when the user has a good impression because of design (Cai and Jun 2003).

\section{Value Added}

Although "Value Added" and "Added Value" terms sound alike and could be used interchangeably in some situations, but still they have different meanings, and the difference in that meaning becomes relevant in different business scenarios, some definitions derives from the its field of science, such as: economics, accounting, operations, marketing and customer behavior, some use Added Value in financial analysis to measure a shareholder value, and calculate it by minus the product price from product cost (Chinomona et al., 2014). While Value Added in economics refer to the estimate of the business economic profit, moreover, market Value Added of any business is the difference between its current market value and the share capital or owners' initial capital. Value Added in business and management comes when the products or services' benefits exceeds the customer expectations and extend to more benefits. In a study carried out by Zeithaml (1988) presented value added as the difference between the evaluation of the benefits perceived by the consumer and the amount practically paid, or that a perceived value is established in the mind of the consumer regarding the relevant service.

Value Added in the online services is not too far, it is customer's perception of the preferred benefits between choosing online services compared with same traditional services. In another words, Value Added refers to extra benefits or features of the online services which make it better than its same traditional one, and provide something exceed customer expectations (Chen et al., 2013). As a practical rule in University's website, presenting the students with high value is a key factor in establishing and maintaining long term student-university relations (Kim-soon, Rahman and Ahmed, 2014). The student's perceived value is when the student believes that the online service is worth, or what he expects to receive if he uses that service. Value added activities are adding customized options to students' services and developing more environmentally friendly services that enhance their services (Kim-soon et al., 2014). In this study we will use the term Value Added, which refer to the total evaluation of the benefits of website services which perceived by the students about what was received (Dlacic et al.; 2014).

Miao et al. (2014) discussed the dimensions of value added which consists of price value, social value, emotional value, and product value. While Kuo et al. (2009), stated that student's perceived value dimensions consist of money value, quality value, beneficial value, and social value. Monetary value refers to the customer's perception when he perceives that he pays less to get the same product or service. Beneficial value refers to the customer's perception when he perceives that the overall estimation of the benefits is deserved (Zeithaml, 1988). Most probably, the students convert everything required to get the service into benefits scale and try to balance their understanding of how much to give and what is available to take in order to get the service.

\section{Student's Value Added of Web-services}

The student perceived value is the difference between a prospective student's evaluation of the benefits of university web-services with traditional university services when compared with competitors. In other words, the tradeoff between the overall benefits that are likely to accrues by using web-services in comparison to existing traditional alternative services, and the overall barriers encountered in using them (Kim-soon et al., 2014). The universities' web-services are online services offered by university's website, such as providing the students with academic and nonacademic information, online applications, online transaction, online payment, and e-learning services. Web-services' Value added can come into two types; monetary value and beneficial (nonmonetary) value. Monetary value of website services happens when a student feel he save money while using university's web-services rather than using tradition university's services, while beneficial value happens when a student feel he got nonmonetary benefits while using 
university's web-services rather than using tradition university's services, such benefits like: psychological benefits, functional benefits, or social benefits.

\section{Dilemma of The Study}

While all universities seeking their students' satisfaction and try to develop their websites to meet that satisfaction, they should focus on the quality of their websites services as one of students' satisfaction determinants, by understanding how students perceive their services' quality, and enhance the websites services accordingly. private universities in Jordan -as all in this field- facing this challenge and should rethink about the framework of developing their website's services to respond to the market competitiveness. Addressing this gap, the study comes to investigate the quality's level of website's services at private universities in Jordan, and its impact on achieving a value added.

Proposed Model of the Study

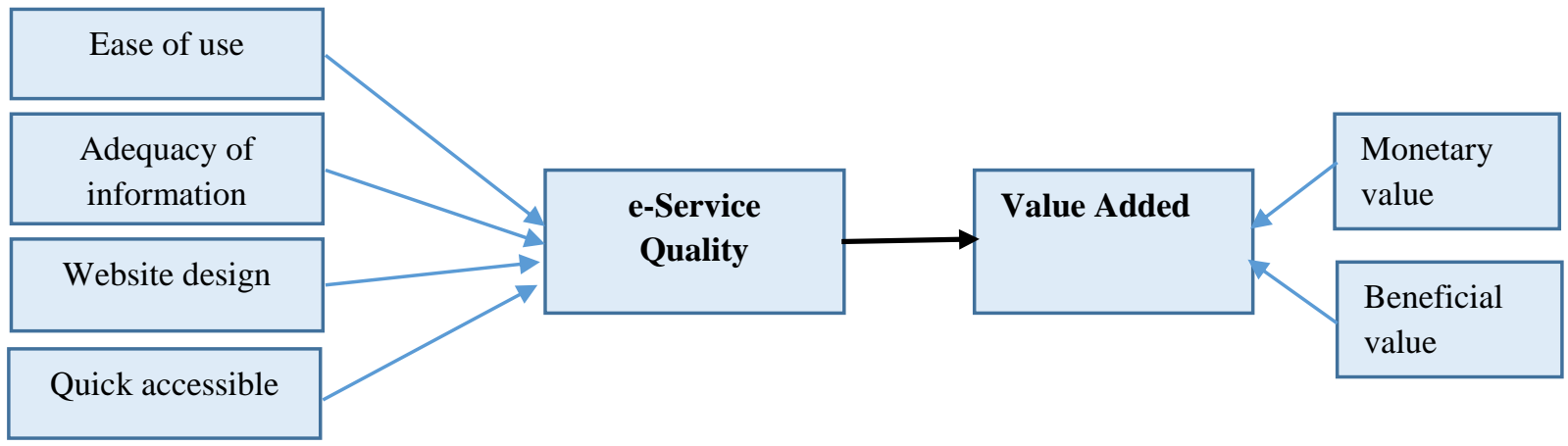

\section{Hypotheses (Null Hypotheses)}

$\mathrm{H}_{\mathrm{O} 1}$ : e-Service Quality have no statistical impact on achieving a Value added at privet universities in Jordan at level $(\alpha \leq 0.05)$.

$\mathrm{H}_{\mathrm{O} 2}$ : e-Service Quality have no statistical impact on achieving a Monetary value at privet universities in Jordan at level $(\alpha \leq 0.05)$.

$\mathrm{H}_{\mathrm{O} 3}$ : e-Service Quality have no statistical impact on achieving a Beneficial value at privet universities in Jordan at level $(\alpha \leq 0.05)$.

\section{Methodology and Study Design}

The methodology of this study considered as descriptive approach. It uses the survey instrument to explore the extent to which the study's dimensions are achieved at the sample of the study. It describes the respondents' perception toward the study's dimensions, in order to analyzes them in terms of available data, moreover, we used the analysis results to prove the hypotheses of the study. The population for this study is the private universities in Jordan, that is sixteen universities, which constitute $57 \%$ of the total universities in Jordan. The private universities were chosen because we believe that the quality of their website services is one of the competitive tools they use. The questionnaire was adopted as a major measurement tool to collect the data, consisting of 30 statements were designed on a five-point Likert-type scales to measure the respondents' perception toward study's dimensions, ranging from (1- strongly disagree) to (5- strongly agree).

All private universities in Jordan are studied. Simple random sampling of 480 students were chosen out of study's population, physical distribution and collection of questionnaires were used on universities campuses, we only distributed to students who already uses the university's website, and we collected 30 students out of each university.

\section{Validity and Reliability}

Content Validity: A number of business management professors and some specialists were asked to review the questionnaire, then the questionnaire was amended in light of their suggestions. 
Internal Consistency: As shown in table 1 the results of Cronbach's Alpha reliability showed that questionnaire items are closely related, since all values of Alpha were "high".

Table 1: Cronbach's Alpha reliability for study's dimensions

\begin{tabular}{|l|l|l|l|}
\hline Dimension & Cronbach's Alpha & Dimension & Cronbach's Alpha \\
\hline e-Service Quality & 0.947 & Quick accessible & 0.885 \\
\hline Value Added & 0.904 & Ease of use & 0.839 \\
\hline Monetary value & 0.778 & Adequacy of information & 0.855 \\
\hline Beneficial value & 0.908 & Website design & 0.872 \\
\hline
\end{tabular}

\section{Data Analysis}

Statistical tools were used to test the validity of the study's model, like descriptive analysis, correlation coefficient, regression and ANOVA analysis, in order to test the proposed relationship of website services' quality and its impact on achieving a value added.

\section{Descriptive Analysis}

Descriptive analysis was used to describe the variables of study, and to show the perception of the respondents toward study's variables and dimensions, then to rank the importance of variables and dimensions regarding their perception. Table 2 shows that the "monetary value" dimension ranked to be the variable with highest importance with mean as 3.47 and Std. as 0.99 , could be because students feel that using the web services have some monetary benefits when compared to same traditional services. Then, the next dimension in the level of importance is "beneficial value", with mean equal to 3.41 and Std. equal to 1.01, after that comes the "website design" dimension with mean equal to 3.39 and Std. equal to 1.01. Then the next dimensions are; "quick accessible, ease of use, and adequacy of information", with means; 3.37, 3.34, 3.31, and Std. 1.06, 1.09, 1.11 respectively.

Table 2: Descriptive analysis for e-Service Quality and Value Added

\begin{tabular}{|c|c|c|c|c|c|c|}
\hline \multicolumn{3}{|c|}{ Variables and dimensions of study } & M & Std. & Sig rank & Sig level \\
\hline \multirow{4}{*}{ 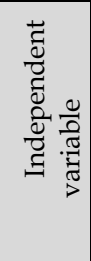 } & \multirow{4}{*}{ 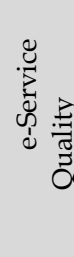 } & Website design & 3.39 & 1.11 & 3 & High \\
\hline & & Adequacy of information & 3.31 & 1.09 & 6 & High \\
\hline & & Quick accessible & 3.37 & 1.02 & 4 & High \\
\hline & & Ease of use & 3.34 & 1.03 & 5 & High \\
\hline \multirow{2}{*}{ 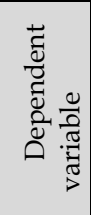 } & \multirow{2}{*}{ 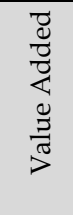 } & Monetary Value & 3.47 & 1.31 & 1 & High \\
\hline & & Beneficial Value & 3.41 & 1.11 & 2 & High \\
\hline
\end{tabular}

All respondents who filled the questionnaire are used the website at their universities, as our policy when questionnaire was distributed to only ask the students who already used their university's website.

Hypothesis 1:

Table 3 shows the results of correlation, ANOVA analysis and regression analysis that examining the effect of e-Service quality on achieving a Value added. Results from correlation analysis showed that a positive relationship exist between e-Service quality and Value added. The value of $r=0.785$ which is positive and strong, it indicates a positive relationship between these two variables. The $\mathrm{r}^{2}=0.716$ which means that 0.716 of changes in "value added" can be explained by variation in "e-service quality". Multiple regression analysis supported that significant relationship exists among "adequacy of 
information" and "value added", where value of $\beta=0.423$, and statistic $t=6.849$ which above $1.64^{* *}$, and $P=.007$ is significance at $\alpha \leq 0.05$ level, similarly, results showed the significant relationship between "website design" and "value added" with $\beta=0.172$, and significant relationship between "quick accessible" and "value added" with $\beta=0.161$, and significant relationship between "ease of use" and "value added" with $\beta=0.137$, where statistic $\mathrm{t}=2.729,2.806,2.126$ respectively, while all $P$ values were significant at 0.05 level. Therefore, we reject the null hypothesis and we can support the alternative hypothesis 1 in the same regard.

Table 3: Correlation, ANOVA and Regression analysis to Value Added in e-Service Quality

\begin{tabular}{|c|c|c|c|c|c|c|c|c|c|}
\hline & $\mathrm{r}$ & $\mathrm{r}^{2}$ & $\mathrm{~F}$ & $\mathrm{DF}$ & Sig* $^{*}$ & $\beta$ & & $\mathrm{t}$ & Sig* $^{*}$ \\
\hline \multirow{4}{*}{ Value Added $t$} & \multirow{4}{*}{0.785} & \multirow{4}{*}{0.617} & \multirow{4}{*}{113.64} & 4 & \multirow{4}{*}{.000} & Website design & 0.172 & 2.729 & 0.034 \\
\hline & & & & \multirow[t]{2}{*}{475} & & $\begin{array}{l}\text { Adequacy of } \\
\text { information }\end{array}$ & 0.423 & 6.849 & 0.007 \\
\hline & & & & & & Quick accessible & 0.161 & 2.806 & 0.022 \\
\hline & & & & 479 & & Ease of use & 0.137 & 2.126 & 0.005 \\
\hline
\end{tabular}

${ }^{*}$ level of significant $(\alpha \leq 0.05){ }^{* *}$ Critical $\mathrm{t}(\mathrm{df} / \mathrm{p})=1.64$

\section{Hypothesis 2:}

Table 4 shows the results of correlation, ANOVA analysis and regression analysis to examine the effect of e-Service quality on achieving a Monetary value. Results of correlation analysis showed that a positive relationship exist between e-Service quality and Monetary value. The value of $r=0.732$ which is positive and strong, it indicates a positive relationship between these two variables. The $r^{2}=0.535$ means that 0.535 of changes in "monetary value" can be explained by variation in "e-service quality". Multiple regression analysis supported that significant relationship exists among "quick accessible" and "monetary value", where value of $\beta=0.452$, and statistic $t=6.666$ which above 1.64 , and $P=.000$ is significance at 0.05 level, similarly, results showed the significant relationship between "adequacy of information" and "monetary value" with $\beta=0.141$, and statistic $\mathrm{t}=2.040$ which above 1.64 , and $\mathrm{P}=0.042$ is significance at 0.05 level. While no significant impact could be found for both "website design" and "ease of use" since statistic " $\mathrm{t}$ " not significant at 0.05 level. Therefore, hypothesis 2 could be supported partially in this study.

Table 4: Correlation, ANOVA and Regression analysis to Monetary Value in e-Service Quality

\begin{tabular}{|c|c|c|c|c|c|c|c|c|c|}
\hline & $\mathrm{r}$ & $\mathrm{r}^{2}$ & $\mathrm{~F}$ & & Sig* & \multicolumn{2}{|l|}{$\beta$} & $\mathrm{t}$ & Sig* \\
\hline \multirow{4}{*}{ Monetary Value } & \multirow{4}{*}{0.732} & \multirow{4}{*}{0.535} & \multirow{4}{*}{83.587} & 4 & \multirow{4}{*}{.000} & Website design & 0.122 & 1.728 & 0.085 \\
\hline & & & & \multirow[t]{2}{*}{475} & & $\begin{array}{l}\text { Adequacy of } \\
\text { information }\end{array}$ & 0.141 & 2.040 & 0.042 \\
\hline & & & & & & Quick accessible & 0.452 & 6.666 & 0.007 \\
\hline & & & & 479 & & Ease of use & 0.116 & 1.852 & 0.065 \\
\hline
\end{tabular}

${ }^{*}$ level of significant $(\alpha \leq 0.05)$

\section{Hypothesis 3:}

Table 5 shows the results of correlation, ANOVA analysis and regression analysis for examining the effect of e-Service quality on achieving a Beneficial value. Results of correlation analysis showed that a positive relationship exist between e-Service quality and Beneficial value. The value of $r=0.579$ which is positive and support the relationship between these two variables. The $r^{2}=0.335$ means that 0.335 of changes in "beneficial value" can be explained by variation in "e-service quality". Multiple regression analysis supported that significant relationship exists among "website design" and "beneficial value", where value of $\beta=0.535$, and statistic $t=5.391$ which above 1.64 , and $P=.000$ is significance at 0.05 level, similarly, results showed the significant relationship between "adequacy of information" and "beneficial value" with $\beta=0.189$, and significant relationship between "ease of use" and "beneficial value" with $\beta=$ 0.186 , also significant relationship between "quick accessible" and "beneficial value" with $\beta=0.138$, where statistic $\mathrm{t}=3.114,2.782,2.025$ respectively, while all $P$ value were significant at 0.05 level. Therefore, we reject the null hypothesis, and we can support alternative hypothesis 3 in this study. 
Table 5 Correlation, ANOVA and Regression analysis to Beneficial Value in e-Service Quality

\begin{tabular}{|c|c|c|c|c|c|c|c|c|c|}
\hline & $\mathrm{r}$ & $\mathrm{r}^{2}$ & $F$ & DF & Sig* $^{*}$ & \multicolumn{2}{|l|}{$\beta$} & $t$ & Sig* \\
\hline \multirow{4}{*}{ Beneficial Value } & \multirow{4}{*}{0.761} & \multirow{4}{*}{0.579} & \multirow{4}{*}{93.782} & 4 & \multirow{4}{*}{.000} & Website design & 0.353 & 5.391 & 0.003 \\
\hline & & & & 75 & & $\begin{array}{l}\text { Adequacy of } \\
\text { information }\end{array}$ & 0.189 & 3.114 & 0.002 \\
\hline & & & & & & Quick accessible & 0.138 & 2.025 & 0.044 \\
\hline & & & & 79 & & Ease of use & 0.186 & 2.782 & 0.006 \\
\hline
\end{tabular}

${ }^{*}$ level of significant $(\alpha \leq 0.05)$

\section{Results Discussion}

The results in Table 3, 4, 5 provide support for the three alternative hypotheses $(\mathrm{H} 1, \mathrm{H} 2, \mathrm{H} 3)$. Hypothesis: 1 posited a positive relationship between e-Service quality and Value added, multiple regression results in Table 3 prove the impact of all e-Service dimensions (website design, adequacy of information, quick accessible and ease of use) on achieving Value added. Moreover, Hypothesis 2 posited a positive relationship between e-Service quality and Monetary value, multiple regression results in Table 4 prove the impact of "adequacy of information" and "quick accessible" on "monetary value", but fail to address the impact of "website design" and "ease of use". Furthermore, Hypothesis 3 posited a positive relationship between e-Service quality and Beneficial value, multiple regression results in Table 5 prove the impact of all e-Service dimensions (website design, adequacy of information, quick accessible and ease of use) on achieving Beneficial value. Regarding analyzing the dimensions of "e-service quality", we found that "adequacy of information" and "website design" were the highest dimensions to impact achieving "value-added" with $\beta=0.423, \beta=0.172$ respectively, at $\mathrm{P}<0.05$. similarly, we found that "quick accessible" and "adequacy of information" were the highest dimensions to impact achieving "monetary value" with $\beta=0.452, \beta=0.141$ respectively, at $\mathrm{P}<0.05$. In addition to that, we found that "website design" and "adequacy of information" were the highest dimensions to impact achieving "monetary value" with $\beta$ $=0.353, \beta=0.189$ respectively, at $\mathrm{P}<0.05$. Similar to our study by (Cetinsoz, 2013; Chen et al., 2013; Chinomona et al., 2014; Pearson et al., 2012) their results showed a positive impact of e-service quality on perceived value. Besides, students do consider perceived e-service quality when evaluating their website's benefits for substitute services from their universities.

\section{Conclusion}

This study came to examine the validity of the e-Service quality in achieving a Value added, and the dimensions in this study were chosen to fit the universities industry, since the requirement of industryspecific measures of e-service quality may different from different industries, also e-service quality could be differentiated in different regions since countries have different cultures that may impact consumer perception and quality understanding. The study found that the students would like get benefits from using the website's services as stimulator to use it, such as saving some money or time, so they feel it add monetary value. The study also highlighted the importance for the universities to improve their services' quality of its website in a continuous manner, by comparing its services with best in the market and explore the students need and requirements, then enhance it accordingly. When universities spend money to develop their website, they should ensure whether their new services will go toward achieving a valueadded benefit, universities also should seek whether development activities worthy. Universities should check in advance whether development activities worthy, and its website services may add benefits to their students. Also, they should examine the students' perception to be sure if students want and understand that benefits, and the development cost of that activities leads to financial payback.

\section{References}

Alzoubi, H., Mohammad, S. and Abu-salma, A (2015). 'Evaluating Strategic Quality Management Dimensions Using Analytic Hierarchy Process (AHP) and its Impact on Organizational Success', International Journal of Research in Management, Vol.5, No.1, pp.137-150.

Askari, M., Kazempoor, M., Saedi, H.; Eslamirad, A. and Lajevardi, M. (2016) 'Measuring E-Service Quality from the Customers' Perspective: An Empirical Study on Banking Services', Journal of Marketing and Consumer Research, Vol.24, pp.57-68. 
Cai, S. and Jun, M. (2003) 'Internet users' perceptions of online service quality: a comparison of online buyers and information searchers', Managing Service Quality: An International Journal, Vol.13, No.6, pp.504-519.

Chen, M., Tsai, K., Hsu, Y. and Lee, K. (2013) 'E-service Quality Impact on Online Customer's Perceived Value and Loyalty', China-USA Business Review, Vol.12, No.5, pp.473-485.

Chinomona, R., Masinge, G. and Sandada, M. (2014) 'The Influence of E-Service Quality on Customer Perceived Value, Customer Satisfaction and Loyalty in South Africa', Mediterranean Journal of Social Sciences, Vol.5, No.9, pp.331-341.

Cristobal, E., Flavian, C. and Guinaliu, M. (2007) 'Perceived e-service quality (PeSQ): Measurement validation and effects on consumer satisfaction and web site loyalty', Managing Service Quality: An International Journal, Vol.17, No.3, pp.317-340.

Dlacic, J., Arslanagic, M., Kadic-Maglajlic, S., Markovic, S. and Raspor, S. (2014) ‘Exploring perceived service quality, perceived value, and repurchase intention in higher education using structural equation modelling',. Total Quality Management E Business Excellence, Vol.25, No.1-2, pp.141-157.

Khafajy, N., Alzoubi, H. and Aljanabee, A. (2016) 'Analyzing the effect of knowledge management processes in the services' quality in Iraqi commercial banks', International Review of Management and Business Research, Vol.5, No.1, pp.302-314.

Kim-soon, N., Rahman, A. and Ahmed, M. (2014) 'E-Service Quality in Higher Education and Frequency of Use of the Service', International Education Studies, Vol.3, No.3, pp.1-10.

Kuo, Y.F., Wu, C.M. and Deng, W.J. (2009) 'The relationships among service quality, perceived value, customer satisfaction, and post-purchased intention in mobile value-added services', Computers in Human Behavior, Vol.25, No.4, pp.887-896.

Ladhari, R. (2010) 'Developing e-Service quality scales: A literature review', Journal of Retailing and Consumer Services, Vol.17, pp.464-477.

Li, H. and Suomi, R. (2009) 'A Proposed Scale for Measuring E-service Quality', International Journal of u-and e-Service, Science and Technology, Vol.2, No.1, pp.1-10.

Miao, R., Cao, J., Zhang, K., Chen, B., Jiang, Z. and Wang, L. (2014) 'Value-added path of service-oriented manufacturing based on structural equation model: the case of electric car rental for instance', International Journal of Production Research, Vol.52, No.18, pp.5502-5513.

Parasuraman, P., Zeithaml, V. and Malhotra, A. (2005) 'E-S-Qual: A Multiple-Item Scale for Assessing Electronic Service Quality', Journal of Service Research, Vol.7, No.3, pp.213-233.

Pearson, A., Suresh, T. and Chris, G. (2012) 'The Role of E-Service Quality and Information Quality in Creating Perceived Value: Antecedents to Web Site Loyalty', Information Systems Management, Vol.29, No.3, pp.201-15.

Rowley, J. (2006) 'An analysis of the e-service literature: towards a research agenda', Internet Research, Vol.16, No.3, pp.339-359.

Rust, R. and Lemon, K. (2001) 'E-Service and the Consumer', International Journal of Electronic Commerce, Vol.5, No.3, pp.85-101.

Santos, J. (2003) 'E-service quality: a model of virtual service quality dimensions', Managing Service Quality: An International Journal, Vol.13, No.3, pp.233-246.

Zeithaml, V. (1988) 'Consumer Perceptions of Price, Quality, and Value: A Means-End Model and Synthesis of Evidence', Journal of Marketing, Vol.52, pp.2-22. 